\title{
Baropodometrija stopala u odnosu na težinu tijela
}

\author{
Budimir Mijović ${ }^{1}$, Suzana Lencur ${ }^{2}$ \\ ${ }^{1}$ Sveučilište u Zagrebu Tekstilno-tehnološki fakultet, Prilaz baruna Filipovića 28a, 10000 Zagreb, \\ Hrvatska \\ 2Škola za modu i dizajn, Prilaz baruna Filipovića 28, 10000 Zagreb, Hrvatska
}

\section{Sažetak:}

Baropodometrijom se mjerio tlak stopala na površinu tijekom stajanja. Čovječje stopalo prilikom kontakta s podlogom po kojoj se giba uzrokuje silu reakcije. Pomoću plantografa i pur pjene mjerila se dužina stopala te pritisak i sile koje se javljaju između stopala i površine. Istoimeni uređaj našao je veliku primjenu u erogonomiji prvenstveno kod izrade standardnih uložaka za obuću. U cilju što vjernije izrade ortopedskih uložaka i cipela, stopalo ostavlja otisak sa posebno naglašenim uporišnim točkama. $U$ radu je izvršena usporedba pritiska normalnog i deformirang stopala kod muškaraca i žena u odnosu na težinu njihovih tijela. Analizom je dobiveno da deformirano stopalo proizvodi sveukupno veći tlak plantarnog tkiva od normalnog stopala. To djelomično pojašnjava teškoće i nepravilnosti u hodu s kojima se ljudi svakodnevno susreću. Ovim istraživanjem ispitanicima se mjerila težina, visina te površina stopala kod 10 muškaraca i 10 žena sa zdravim i deformiranim stopalom. Nadalje, mjerilo se sila i tlak koje stopalo proizvede hodajući. Promatrajući uporište točke na koje se stopalo oslanja došlo je do zaključka da osobe sa većom težinom proizvedi veći tlak stopala, stvaraju veću silu na podlogu, neovisno o spolu pojedinca. U nadi da će ovo istraživanje pridonijeti večoj proizvodnji ergonomske obuće da bih smanjili opterećenje stopala jer oni su ipak "naši mali nosači velikog tereta".

\section{Ključne riječi:}

Baropodometrija, biomehanika, fiziologija stopala

\section{Uvod}

Stopala sadrži 26 kostiju, 33 zglobovima i oko 100 mišića, ligamenata i tetiva [1]. Kosti stoplja (korijen stopala), ossa tarsi, čini sedam kostiju koje od kostiju potkoljenice preuzimaju opterećenja. Veliko značenje u normalnom hodu imaju svodovi stopala te uporišne točke koje prenose mehaničke sile na podlogu. Stojeći uspravno težina našeg tijela prenosi se kroz sredinu potkoljenice do skočnog zgloba, odnosno do skočne kosti, slika 1. Tu se sada sile težine dijele u dva pravca; jedan dio dopire do oslonca petne kosti, a drugi dio ide prema glavicama svih pet donožnih kostiju [5]. Statika stopala se mijenja ako težina tijela nije uravnotežena te je razlog mnogim stečenim deformitetima stopala [3].
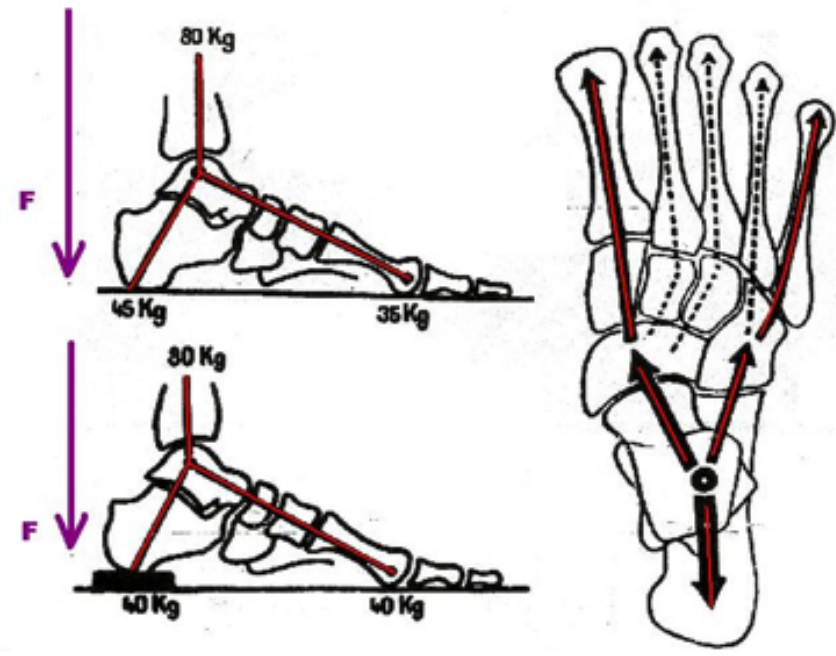

Slika 1. Raspored sila težine tijela na ravnoj podlozi i kod potpetice od 2 $\mathrm{cm}$, te prikaz prenosa sile na sve donožne kosti, a najviše na I i V

Tabanski svod se održava samim rasporedom kostiju stopala, pomoću zglobnih veza i snagom mišića potkoljenice i stopala. Svod se može usporediti sa amortizerima na vozilima jer ublažuje sile težine našeg tijela koje djeluje na stopalo u statici i dinamici. Mehaničkoj funkciji stopala osobito veliko značenje imaju gornji i donji nožni zglob, koji zajedno čine složenu jedinicu te djeluju kao anatomska, funkcionalna i klinička cjelina, slika 2. Statička funkcija stopala ovisi o kostima stopala, ligamentarnom aparatu te o funkciji mišića potkoljenice i stopala [2-4].

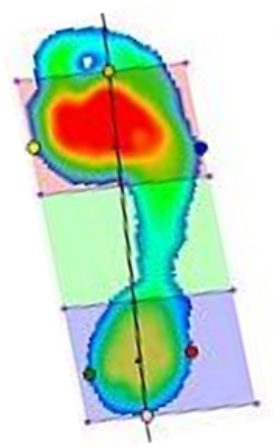

a

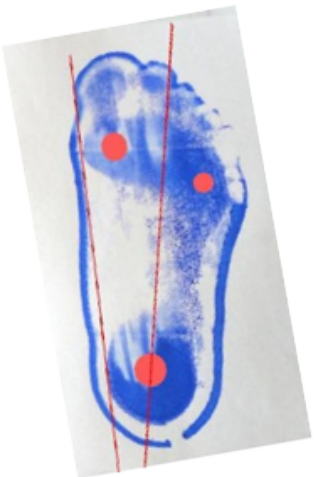

b
Slika 2. Uporišne točke stopala prikazane skenerom i plantografom

\section{Metode i materijali}

Ispitanici su bili deset muškaraca i deset žena sa različitim stopalima (dob 22-75g, visine od 160-191 cm, težine od 60-130 kg.) Za potrebe istraživanja koristio se obućarski centimetar, plantogram i 10 komada pur pjene, slika 3.

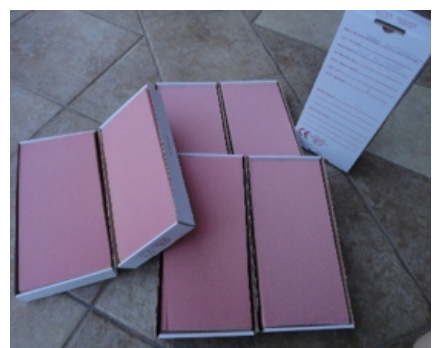

a

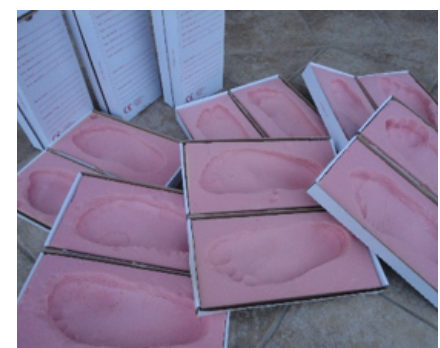

b
Slika 3. Primjer pur pjene za uzimanje otiska stopala te slika desno uzorci otisaka

Ispitanicima je izmjeren otisak stopala u pur pjeni, a nakon toga na plantografu. Evidentirana je masa i visina pojedinog ispitanika. Izmjerila se dužinu stopala i širinu te izračunala površina stopala za svakoga ponaosob. Nakon toga uslijedio je izračun tlaka i sile kojom stopalo djeluje na površinu. Rad međunarodnog tijela za kvalitetu obuće ISO/TC 137 
rezultirao je donošenjem međunarodnog standarda za veličine označivanje obuće ISO 9407:1991. Hrvatski antropometrijski sustav uskladio je određivanje tjelesnih mjera sa ovim standardom. Stvaranjem sustava veličina želi se postići da internacionalni standard bude jedini koj se koristi u mjerenju stopala i na čemu se temelji veličina cipele. Taj sustav mjerenja bazira se na dvije sljedeće mjere: duljina stopala i širina stopala. Opseg stopala i ostale mjere upotrebljavaju se u različitim fazama proučavanja stopala. Duljila stopala je horizontalna udaljenost između najistaknutijeg prsta i najistaknutijeg dijela pete, mjereno u stojećem položaju kako bi se ravnomjerno rasporedila težina tijela na horizontalnu podlogu.[6][7]

\section{Eksperimentalni dio}

Plantograf je uređaj koji radi na principu da se naličje gumirane podloge premaže tintom. Ispod gumirane podloge postavlja se papir za otisak stopala, a na prednju stranu podloge položi se stopalo . Pravilo je da osoba stoji okomito, a težina tijela mora biti raspodijeljena na obje noge. Pritiskom stopala na kožnu podlogu dobivamo otisak na papiru, a nakon toga plastičnom olovkom vršimo ocrtavanje ruba stopala, slika 4 .

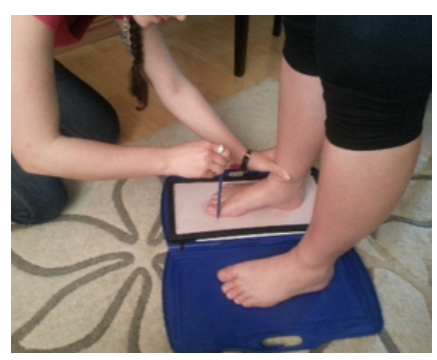

a

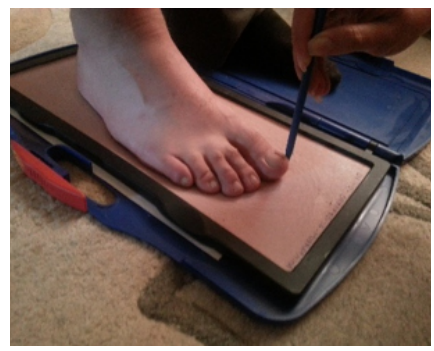

C

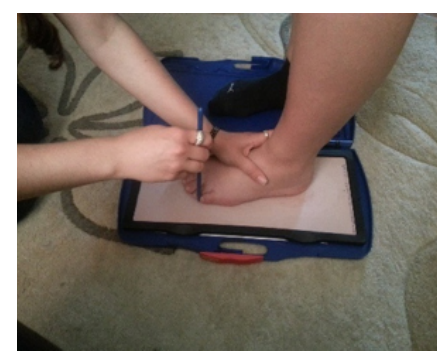

b

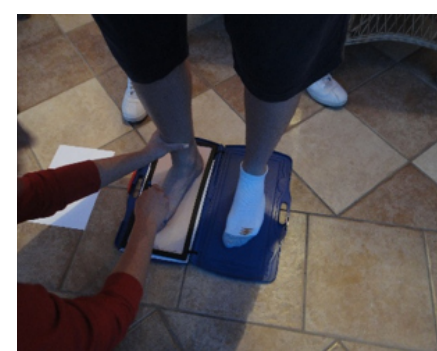

Slike 4. Mjerenje stopala plantografom

Dinamičkim prenošenjem težine tijela, tj. izmjenjivanjem oslonca na jednoj i drugoj drugoj nozi uspostavljamo ravnotežu, slika 5.

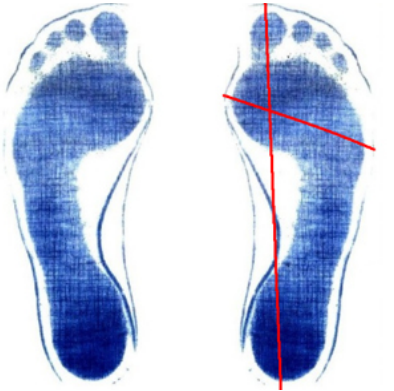

a

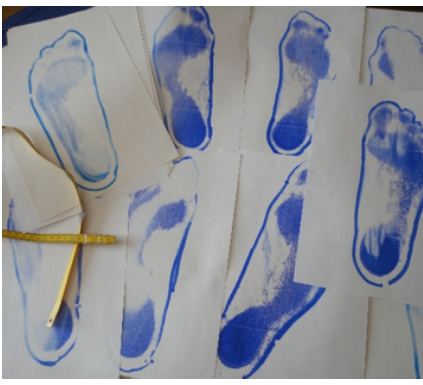

b
Slika 5. Prikaz dužine i širine stopala i otisci stopala

$U$ istraživanju se koristio plantograf $i$ pur pjenu koja je jako zahvalna te još uvijek upotrebljiva u mnogo ortopedskih radnji jer se mogu dobiti negativi stopala. Uzimajući mjere stopala dobila se realna duljinu stopala od najdužeg prsta do pete i širinu stopala kod pregiba prstiju. Kod standardnog stopala u uspravnom stajaćem položaju težina tijela proteže se od prstiju preko metatarzalnih kostiju i srednjeg dijela stopala do pete, dok je kod deformiranog stopala cjelokupna težina tijela koncentrirana na metatarzalnim kostima i srednjem dijelu stopala. Pošto je kod defomiranog stopala tlak cjelokupne težine tijela na metatarzalnim kostima i sredini stopala dolazi do deformacija. Razmatrale su se uporište točke na koje se stopalo oslanja te zaključilo da osobe sa većom težinom proizvedu veći tlak stopala, stvaraju veću silu na podlogu, neovisno o spolu pojedinca.

\section{Rezultati}

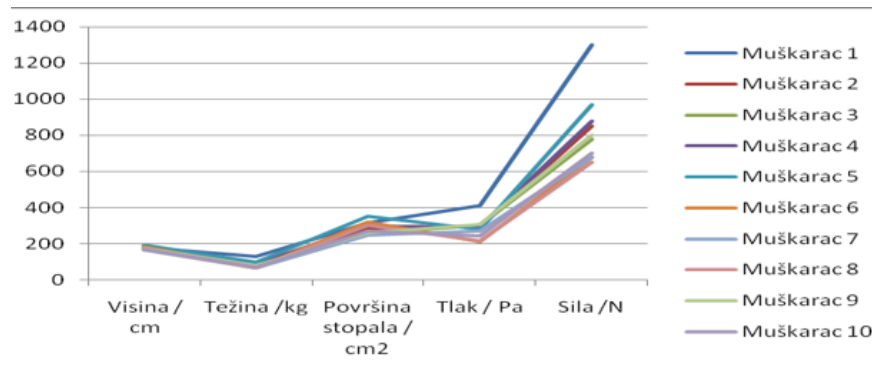

Slika 6. Grafički prikaz mjera kod muškaraca

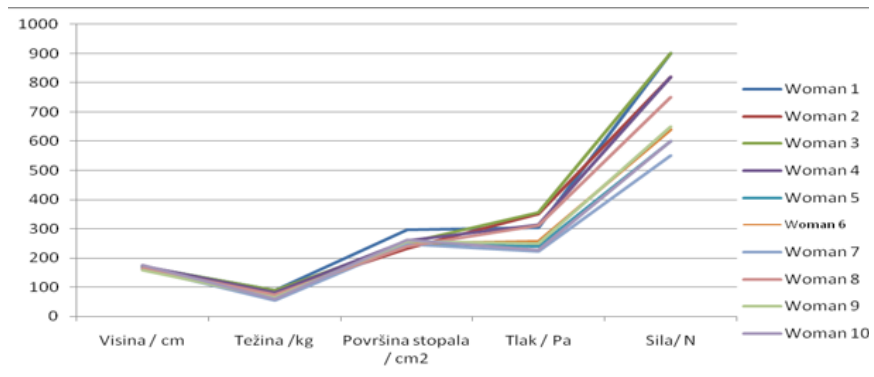

Slika 7. Grafički prikaz mjera kod žena

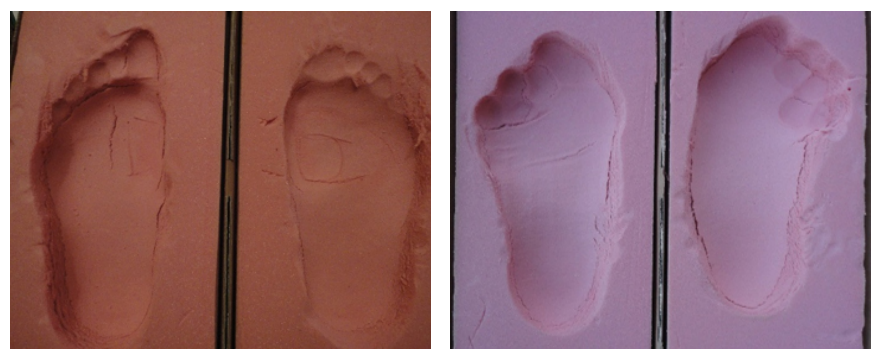

Slika 8. i 9. Otisak u pur pjeni- deformirana stopala koja stvaraju veći tlak od zdravog stopala

\section{Zaključak}

Osobe sa većom težinom proizvedu veći tlak stopala, stvaraju veću silu na podlogu, neovisno o spolu pojedinca. Prikladna obuća ima veliko značenje u čovjekovu životu te kao takva mora biti iskreirana da se izbjegnu mjesta visokih kontaktnih tlakova, odnosno mjesta koncentriranog naprezanja unutar stopala.[6] Mjesta maksimalnog kontaktnog opterećenja su potencijalni žuljevi, otekline, rane, nepravilna geometrijska forma stopala jer su biomehanička zbivanja kod hoda vrlo složena. Pokretanje tijela i održavanje ravnoteže je omogućeno mnogim mehaničkim zbivanjima u kojima najveće značenje imaju sila teža, sila inercije i tlak koje stopalo proizvede bez obzira na spol pojedinca.

\section{Literatura}

[1] Keros P., Matković B.: Anatomija i fiziologija, Lijevak, 2006.

[2] Krmpotić-Nemanić J., Marušić A.: Anatomija čovjeka, Zagreb: Medicinska naklada 2007

[3] Ruszkowski I, Normalan i poremečen hod čovjeka, Jumena, 1981.

[4] Mandić V., Građa i funkcija stopala, Zagreb, 1971.

[5] Cvjetičanin M., Priručnik o stopalu, Zagreb 1991.

[6] Mika A, Oleksy L, Mika P, Marchewka A, Clark B. The influence of hee height on lower extremity kinematics and leg muscle activity during gait in young and middle-aged woman. Gait \& Posture 35 (2012), 4: 677-680

[7] Sato M, Ikeuchi H, Yamashita T. A. correctiong method for outputs of large force plate to study human walking. Transactions of the SICE: 1993; 29 (8):976-978 